\title{
Keefektifan Media Pembelajaran Buku Aktivitas Peta Si Pintar dalam Meningkatkan Motivasi Belajar Siswa
}

\author{
${ }^{1 *}$ M. Risco Indra Riawan, ${ }^{1 S}$. Sukamto, ${ }^{1}$ Ervina Eka Subekti \\ ${ }^{1}$ Jurusan Pendidikan Guru Sekolah Dasar, Fakultas Ilmu Pendidikan Universitas PGRI Semarang \\ (UPGRIS), Jl. Sidodadi Timur No. 24 - Dr.Cipto Semarang, Indonesia \\ *Corresponding Author e-mail: riawanriscoindra1997@gmail.com \\ Received: March 2020; Revised: April 2020; Published: July 2020
}

\begin{abstract}
Abstrak
Tujuan penelitian ini untuk mendeskripsikan keefektifan media pembelajaran Buku Aktivitas Peta Si Pintar (Petualangan di Taman Musik Pintar) dalam meningkatkan motivasi belajar siswa kelas 1 SDN Bugangan 01 Semarang pada materi Tema 2 Kegemaranku, Subtema 2 Gemar Bernyanyi dan Menari. Penelitian ini menggunakan pendekatan kuantitatif dengan rancangan Pre-Experimental Design dengan One-Group pretest-posttest Design. Data penelitian didapatkan menggunakan instrumen berbentuk angket dan soal evaluasi yang telah dinyatakan valid dan reliabel. Hasil penelitian menunjukkan (1) motivasi belajar meningkat skor rata-rata sebelum perlakuan 78,7 dan setelah diberi perlakuan naik menjadi 96,9, (2) Pada hasil soal pretest diperoleh nilai rata-rata sebesar 65,65 dan soal posttest naik menjadi 92,1. Sehingga diperoleh hasil regresi dengan skor $\mathrm{r}^{2}=0,0022$. Hasil penelitian tersebut membuktikan bahwa salah satu faktor yang mempengaruhi prestasi siswa adalah motivasi belajar. Berdasarkan hasil penelitian dapat disimpulkan bahwa penggunaan media pembelajaran Peta Si Pintar (Petualangan di Taman Musik Pintar) dapat meningkatkan motivasi belajar siswa kelas I SDN Bugangan 01 Semarang.
\end{abstract}

Kata Kunci: Media Pembelajaran, Buku Aktivitas Peta Si Pintar, Motivasi Belajar

\section{The Effectiveness of Si Pintar Map Activity Book Learning Media to Increase Student Learning Motivation}

\begin{abstract}
The purpose of this study was to describe the effectiveness of Si Pintar Map Activity Book learning media (Adventure in the Smart Music Park) in increasing student motivation in class 1 at SDN Bugangan 01 Semarang on the subject matter 2 My Favorite, sub-theme 2 Singing and Dancing Favors. This research uses a quantitative approach with a Pre-Experimental Design with One-Group pretest-posttest Design. The research data were obtained using a questionnaire instrument and evaluation questions that were declared valid and reliable. The results showed (1) learning motivation increased the average score before treatment 78.7 and after being given treatment rose to 96.9 , (2) the results of the pretest questions obtained an average value of 65.65 and posttest questions rose to 92,1 . So that the regression results obtained with a score of $r^{2}=0.0022$. The results of the study prove that one of the factors that influence student achievement is learning motivation. Based on the results of the study it can be concluded that the use of Si Pintar Map Activity Book learning media (Adventure in the Smart Music Park) can increase student motivation in class I SDN Bugangan 01 Semarang.
\end{abstract}

Keywords: Learning Media, Si Pintar Map Activity Book, Learning Motivation

How to Cite: Riawan, M., R., Sukamto, S., \& Subekti, E., E. (2020). Keefektifan Media Pembelajaran Buku Aktivitas Peta Si Pintar dalam Meningkatkan Motivasi Belajar Siswa. Jurnal Penelitian dan Pengkajian Ilmu Pendidikan: e-Saintika, 4(2), 95-104. doi:https://doi.org/10.36312/e-saintika.v4i2.193 


\section{PENDAHULUAN}

Pembelajaran tematik adalah pembelajaran yang diterapkan di sekolah dasar. Sesuai denagn peraturan Permendikbud No. 65 tahun 2013 tentang standar proses pada kurikulum 2013 bahwa di sekolah dasar pembelajaran diterapkan pendekatan tematik-integrasi. Pembelajaran tematik adalah pembelajaran yang memadukan pengetahuan secara komprehensif dan terintegrasi (Ain \& Kurniawati, 2013). Pembelajaran tematik merupakan suatu pembelajaran yang mengaitkan beberapa mata pelajaran menjadi satu tema, sehingga materi lebih ringkas dan anak menjadi lebih paham (Wahyuni et al., 2016). Perubahan kurikulum menyebabkan adanya kesenjangan kemampuan guru dalam mengimplementasikan. Sedangkan guru yang mengajar di SD masih tahap penyesuaian untuk mencari-cari bagaimana cara mengajar yang tepat.

Kemampuan guru dalam mengajar pembelajaran tematik yang tepat tidak hanya kemampuan dalam kegiatan mengajar saja akan tetapi terdapat berbagai komponen pembelajaran yang dapat meningkatkan pembelajaran. Salah satu komponen yang dapat meningkatkan pembelajaran adalah media pembelajaran. Kunci sukses dalam pelaksanaan proses belajar adalah media pembelajaran (Qondias et al., 2016). Pemilihan media haruslah tepat sesuai kebutuhan (Dewanti et al., 2013). Dengan pemilihan media tepat memudahkan dalam menyerap materi karena fungsi setiap media mempunyai kemampuan berbeda. Media pembelajaran digunakan untuk memperudah memberikan materi dari guru kepada siswa sebagai penunjang dalam kegiatan pembelajaran. Adanya media pembelajaran diharapkan mampu meningkatkan motivasi belajar siswa.

(Baharun, 2016) mengatakan bahwa media pembelajaran hanya sebagai alat bantu yang dapat memberikan pengalaman visual guna memotivasi belajar untuk memperjelas dan mempermudah konsep pemahaman anak dalam tahap berfikir anak SD yaitu pada tahap operasionl konkrit. Motivasi adalah faktor kunci dalam belajar. Motivasi adalah usaha sadar seseorang untuk belajar atau melakukan suatu kegiatan. Siswa belajar karena didorong oleh kekuatan mentalnya (Dimyati \& Mudjiono, 2015).

Kondisi riil di lapangan kendalanya yakni masih kurangnya pengunaan media pembelajaran berbasis tematik. Adanya peralihan kurikulum ini sehingga belum disertai keseimbangan dalam pengunaan komponen-komponen pembelajaran. Munculnya masalah di dalam kelas disebabkan dari siswa maupun guru (Maghfiroh, 2006). Guru cenderung mengimplementasikan dengan kondisi kemampuan dan fasilitas yang ada, seperti penggunakan komponen pembelajaran media pembelajaran seadanya, sehingga siswa kurang minat mengikuti pelajaran karena sulit memahami materi yang disampaikan oleh guru. Pada siswa SD perkembangan berpikir anak masih pada tahap operasional konkrit. Tahap ini kecenderungan belajar memiliki tiga ciri, yaitu konkrit, integrasi, dan hirarkis Piaget dalam (Worowirastri E. et al., 2018). Pembelajaran konkrit yakni proses belajar dimulai dari hal yang dapat dilihat, diraba dan sesuai dengan bentu aslinya tidak dalam bentuk replika ataupun bentuk benda contoh menyerupainya. Terutama di kelas 1 SD yang cara berpikirnya pada tahap pembelajaran operasional konkrit. Sehingga membutuhkan media pembelajaran menarik,kretaif dan inovatif untuk memudahkan dalam memahami materi pembelajaran. Keberhasilan dalam kegiatan pembelajaran dilihat dari adanya perubahan tingkah laku aktivitas belajar (aktivitas fisik, mental dan emosional) peserta didik secara optimal pada saat proses pembelajaran (Octaviani, 2017). Pada 
hakekatnya proses belajar yakni kegiatan komunikasi dalam menyampaikan pesan dari pembicara kepada penyimak (Nurryna, 2009).

Berdasarkan hasil pengamatan yang dilakukan dengan guru kelas 1 SD $\mathrm{N}$ Bugangan 01 Semarang ditemukan beberapa kendala antara lain: 1) kurangnya antusias siswa pada pembelajaran yang berlangsung. Hal ini dikarenakan guru belum memanfaatkan media pembelajaran yang sesuai kurikulum 2013 yaitu media berbasis tematik, menarik dan inovatif memotivasi belajar siswa sehingga siswa kurang antusias untuk mengikuti pembelajaran. 2) percaya diri siswa masih rendah karena kurangnya melibatkan siswa dalam pembelajaran. 3) pembelajaran masih berpusat pada guru. Dari beberapa poin yang disebutkan dapat dikatakan bahwa motivasi belajar siswa masih rendah. Pembelajaran bisa menjadi lebih menarik apabila strategi guru dalam mengajar memberikan kesempatan siswa lebih aktif dan terlibat langsung dalam kegiatan belajar sehingga siswa lebih memahami dan mengingat materi yang disampaikan oleh guru (Nataliya, 2011). Giat atau tidaknya seseorang belajar dapat dipengaruhi oleh berbagai faktor, salah satunya adalah motivasi (Ulfah et al., 2016). "Motivasi belajar akan muncul ketika siswa memiliki kemauan dan keingian untuk melakukan suatu kegiatan sehingga tujuan bisa tercapai" (Uno, 2016). "Motivasi yaitu usaha untuk memunculkan minat seseorang untuk melakukan kegiatan, dan apabila seseorang tidak suka maka tidak melakukan sebuah kegiatan" (Sardiman, 2006) dalam (Handhika, 2012). Maka perlu adanya minat dan kemauan belajar siswa dalam meningkatkan motivasi agar pembelajaran lebih aktif dan tujuan pembelajaran bisa tercapai dengan lancar. Guru dapat melakukan pembelajaran dengan menggunakan media yang menarik, interaktif, inovatif memotivasi belajar siswa dan sesuai dengan Kurikulum 2013 pembelajaran tematik.

Penerapan media pembelajaran Buku Aktivitas telah berhasil dilakukan sebelumnya yaitu penelitian dari (Untari et al., 2019) yang berjudul "Pengembangan Media Quiet Book untuk Pembelajaran Tematik Keluargaku Sekolah Dasar Kelas I", diperoleh kesimpulan bahwa media Quiet Book memiliki pengaruh terhadap pemahaman pembelajaran tematik. Hal ini dilihat dari Hasil uji coba perorangan, jumlah skor yang diperoleh mencapai 42,6 dengan rata - rata 4,26. Berdasarkan pedoman konversi data kuantitatif ke kualitatif maka media Quiet Book termasuk dalam kategori baik. Saat peserta didik menggunakan media Quiet Book, mereka terlihat senang dan tertarik menggunakan media Quiet Book. Mereka juga terlihat antusias dalam mencoba memainkan media Quiet Book. Persamaan penelitian diatas dengan peneliti sendiri adalah sama-sama menerapkan media Quiet Book tetapi yang digunakan media peneliti sendiri bernama Activity Book. Kedua istilah tersebut memiliki arti dan tujuan sama salah satunya untuk mengedukasi kegiatan belajar dengan konsep belajar sambil bermain.

Berdasarkan permasalahan diatas peneliti memiliki tujuan untuk mengetahui keefektifan media pembelajaran Peta Si Pintar (Petualangan di Taman Musik Pintar) terhadap motivasi belajar Tema 2 kegemaranku Subtema 2 Gemar Bernyanyi dan Menari siswa kelas I SD Bugangan 01 Semarang.

\section{METODE PENELITIAN}

Metode penelitian yang digunakan dalam penelitian ini menggunakan metode ilmiah pada dasarnya merupakan cara ilmiah untuk mendapatkan data dengan tujuan dan kegunaan tertentu. Metode yang digunakan dalam penelitian ini adalah metode penelitian kuantitatif. 
Desain penelitian menggunakan jenis rancangan Pre-Experimental Design dengan bentuk desain penelitian One-Group pretest-posttest Design.

$\mathrm{O} 1 \times \mathrm{O}_{2}$

Gambar 1. Desain Eksperimen (Sugiyono, 2010)

Keterangan :

O1 : nilai pretest (nilai motivasi belajar sebelum diberi perlakuan media pembelajaran Buku Peta Si Pintar)

O2 : nilai posttest (nilai motivasi belajar sesudah diberi perlakuan media pembelajaran Buku Peta Si Pintar).

$\times \quad$ : perlakuan dengan media pembelajaran Buku Aktivitas Peta Si Pintar, Petualangan di Taman Musik Pintar terhadap motivasi belajar.

Penelitian ini bertujuan untuk mengetahui efektifitas media pembelajaran Peta Si Pintar (Petualangan di Taman Musik Pintar) motivasi belajar siswa kelas 1 SD N Bugangan 01 Semarang. Sekolah yang akan dijadikan lokasi penelitian adalah Penelitian dilaksanakan di SD N 01 Bugangan Semarang Jalan Bugangan 0, Bugangan, Semarang Timur, Rejosari, Kecamatan kota Semarang timur, Jawa Tengah waktu penelitian dilakukan pada semester gasal tahun pelajaran 2019/2020, karena materi yang diambil terdapat pada semester gasal kelas 1.

Berdasarkan hasil uji validitas angket motivasi belajar terdapat 30 pernyataan yang valid 10 pernyataan yang tidak valid dan reliabilitas diperoleh $r_{\text {hitung }}=0.817$ dengan kategori reliabilitas sangat tinggi. Sedangkan hasil uji validitas soal evaluasi terdapat 22 pernyataan yang valid 3 pernyataan yang tidak valid dan reliabilitas diperoleh $r_{\text {hitung }}=0.905$ dengan kategori reliabilitas sangat tinggi sehinggainstrumen yang digunakan oleh peneliti adalah (1) Lembar Observasi, (2) tes, (3) Angket, (4) wawancara, (5) dokumentasi untuk mengumpulkan mengumpulkan data selama proses penelitian.

Selanjutnya teknik analisis data kuantitatif digunakan untuk mengetahui dan menjawab hipotesis penelitian yang berkaitan dengan perbedaan media pembelajaran Peta Si Pintar (Petualangan di Taman Musik Pintar) dengan pembelajaran konvensional. Tahapan analisis data kuantitatif dengan menggunakan statistik dilakukan dengan tahapan-tahapan yaitu (1) analisis uji normalitas, (2) analisis uji beda dengan menggunakan uji t atau uji lain yang sesuai, (3) analisis motivasi belajar, (4) analisis uji beda dengan menggunakan N- Gain., (5) analisis regresi linier sederhana.

\section{HASIL DAN PEMBAHASAN}

Hasil penelitian didapat dari dua cara yaitu hasil pretest dan posttest. Dimana pretest merupakan hasil motivasi belajar siswa sebelum diberi perlakuan dan posttest merupakan hasil motivasi belajar siswa setelah diberikan perlakuan menggunakan media pembelajaran Buku Aktivitas Peta Si Pintar (Petualangan di Taman Musik Pinta). Penelitian ini bertujuan untuk mengetahui keefektifan media pembelajaran Buku Aktivitas Peta Si Pintar (Petualangan di Taman Musik Pinta) Terhadap Motivasi Belajar Siswa Tema 2 Kegemaranku Subtema 2 Gemar Bernyanyi Dan Menari Kelas I SD N Bugangan 01 Semarang. Dalam melakukan penelitian peneliti memilih menggunakan kelas I sebagai sampel penelitian, jumlah sampel yang digunakan peneliti sebanyak 20 siswa dari 28 siswa yang terdiri dari 18 siswa laki-laki dan 20 
siswa perempuan. Peneliti menggunakan metode penelitian Pre-Experimen Design dengan jenis One-Group Pretest-Posttest Design dengan memiliki tujuan untuk melihat akibat dari sebuah perlakuan yang diberikan. Kelas yang digunakan dalam penelitian ini hanya satu kelas yaitu kelas I dengan melakukan penelitian selama tiga hari.

Data hasil penelitian diperoleh dari nilai pretest dan posttest dinyatakan tuntas jika memenuhi nilai KKM. Dengan Kriteria Ketuntasan Maksimal (KKM) pada pembelajaran tematik yaitu 70. Perhitungan nilai pretest dan nilai posttest setelah diberikan perlakuan hasilnya berbeda.

Data hasil angket sebelum diberi perlakuan ini digunakan untuk melihat motivasi belajar siswa kelas 1 SD N Bugangan 01 Semarang sebelum diberi perlakuan menggunakan media pembelajaran Peta Si Pintar (Petualangan di Taman Musik Pintar) dari hasil data tersebut dapat disusun dalam Tabel 1.

Tabel 1. Distribusi Skor Angket Sebelum Diberi Perlakuan Siswa kelas 1 SDN Bugangan 1 Semarang.

\begin{tabular}{llll}
\hline Skor Angket Awal & Frekuensi & Perentase & Kiteria \\
\hline $67-71$ & 4 & $20 \%$ & Sedang \\
$72-76$ & 3 & $15 \%$ & Sedang \\
$77-81$ & 6 & $30 \%$ & Sedang \\
$82-86$ & 4 & $20 \%$ & Sedang \\
$87-91$ & 3 & $15 \%$ & Sedang \\
\hline Jumlah & 20 & $100 \%$ & \\
\hline
\end{tabular}

Berdasarkan Tabel 1 menyatakan bahwa terdapat empat siswa yang mendapatkan skor angket dalam rentang 67-71 dengan presentase 20\% dengan kriteria sedang, tiga siswa yang mendapatkan skor angket dalam rentang 72-76 dengan presentase $15 \%$ dengan kriteria sedang, enam siswa yang mendapatkan skor angket dalam rentang 77-81 dengan presentase 30\% dengan kriteria sedang, empat siswa yang mendapatkan skor angket dalam rentang 82-86 dengan presentase 20\% dengan kriteria sedang, tiga siswa yang mendapatkan skor angket dalam rentang 8791 dengan presentase $15 \%$ dengan kriteria sedang.

Data hasil angket setelah diberi perlakuan ini digunakan untuk melihat motivasi belajar siswa kelas 1 SD $\mathrm{N}$ Bugangan 01 Semarang setelah diberi perlakuan menggunakan media pembelajaran Peta Si Pintar (Petualangan di Taman Musik Pintar) dari hasil data tersebut dapat disusun dalam Tabel 2.

Tabel 2. Distribusi Skor Angket Setelah Diberi Perlakuan Siswa kelas 1 SD N Bugangan 1 Semarang

\begin{tabular}{llll}
\hline Skor Angket Awal & Frekuensi & Perentase & Kiteria \\
\hline $84-88$ & 3 & $15 \%$ & Sedang \\
$89-93$ & 2 & $10 \%$ & Sedang \\
$94-98$ & 6 & $30 \%$ & Tinggi \\
$99-103$ & 7 & $35 \%$ & Tinggi \\
$104-108$ & 2 & $10 \%$ & Tinggi \\
\hline Jumlah & 20 & $100 \%$ & \\
\hline
\end{tabular}

Berdasarkan Tabel 2 menyatakan bahwa terdapat tiga siswa yang mendapatkan skor angket dalam rentang 84-88 dengan presentase 15\% dan kriteria sedang, dua siswa yang mendapatkan skor angket dalam rentang 89-93 dengan presentase 10\% dan kriteria sedang, enam siswa yang mendapatkan skor angket dalam rentang 94-98 
dengan presentase 30\% dan kriteria tinggi, tujuh siswa yang mendapatkan skor angket dalam rentang 99-103 dengan presentase 35\% dan kriteria tinggi, dua siswa yang mendapatkan skor angket dalam rentang 104-108 dengan presentase $10 \%$ dan kriteria tinggi.

Berdasarkan Tabel 1 dan Tabel 2 hasil angket sebelum diberi perlakuan dan setelah diberi perlakuan dapat disimpulkan bahwa ada peningkatan skor sebelum diberi perlakuan dan sesudah diberi perlakuan. Hal ini terbukti dengan skor angket sebelum diberi perlakuan terendah 67 dan skor angket tertinggi 90 dengan rata-rata 78,7. Sedangkan skor angket setelah diberi perlakuan terendah 84 dan skor angket tertinggi 108 dengan rata-rata 96,9.

Data hasil soal evaluasi sebelum diberi perlakuan ini digunakan untuk melihat kemampuan hasil belajar siswa kelas 1 SD N Bugangan 01 Semarang sebelum diberi perlakuan menggunakan media pembelajaran Peta Si Pintar (Petualangan di Taman Musik Pintar) dari hasil data tersebut dapat disusun dalam Tabel 3.

Tabel 3. Distribusi Skor Soal Evaluasi Sebelum Diberi Perlakuan Siswa Kelas 1 SD N Bugangan 1 Semarang

\begin{tabular}{lllc}
\hline Skor Angket Awal & Frekuensi & Perentase & Kiteria \\
\hline $14-27$ & 1 & $5 \%$ & Belum Tercapai \\
$28-41$ & 0 & $0 \%$ & - \\
$42-55$ & 2 & $10 \%$ & Belum Tercapai \\
$56-69$ & 8 & $40 \%$ & Belum Tercapai \\
$70-83$ & 9 & $45 \%$ & Sudah Tercapai \\
\hline Jumlah & 20 & $100 \%$ & \\
\hline
\end{tabular}

Berdasarkan Tabel 3 menyatakan bahwa terdapat satu siswa yang mendapatkan skor evaluasi dalam rentang 14-27 dengan presentase 5\% dengan kriteria belum tercapai, tidak ada siswa yang mendapatkan skor evaluasi dalam rentang 28-41 dengan presentase $0 \%$ dengan kriteria belum tercapai, dua siswa yang mendapatkan skor angket dalam rentang 42-55 dengan presentase 10\% dengan kriteria belum tercapai, delapan siswa yang mendapatkan skor angket dalam rentang 56-69 dengan presentase $40 \%$ dengan kriteria belum tercapai, sembilan siswa yang mendapatkan skor angket dalam rentang 70-83 dengan presentase $45 \%$ dengan kriteria sudah tercapai.

Data hasil setelah diberi perlakuan ini digunakan untuk melihat peningkatan hasil belajar siswa kelas I SD N Bugangan 01 Semarang setelah diberi perlakuan menggunakan media pembelajaran Buku Aktivitas Peta Si Pintar (Petualangan di Taman Musik Pintar) dari hasil data tersebut dapat disusun dalam Tabel 4.

Tabel 4. Distribusi Skor Soal Evaluasi Setelah Diberi Perlakuan Siswa kelas 1 SDN Bugangan 1 Semarang

\begin{tabular}{lllc}
\hline Skor Angket Awal & Frekuensi & Perentase & Kiteria \\
\hline $73-77$ & 2 & $10 \%$ & SudahTercapai \\
$78-82$ & 0 & $0 \%$ & - \\
$83-87$ & 3 & $15 \%$ & Sudah Tercapai \\
$88-92$ & 4 & $20 \%$ & Sudah Tercapai \\
$93-97$ & 6 & $30 \%$ & Sudah Tercapai \\
$98-100$ & 5 & $25 \%$ & Sudah Tercapai \\
\hline Jumlah & 20 & $100 \%$ & \\
\hline
\end{tabular}


Berdasarkan Tabel 4 menyatakan bahwa terdapat dua siswa yang mendapatkan skor evaluasi dalam rentang 73-77 dengan presentase $10 \%$ dengan kriteria sudah tercapai, tidak ada siswa yang mendapatkan skor evaluasi dalam rentang 78-82 dengan presentase $0 \%$, tiga siswa yang mendapatkan skor angket dalam rentang 8387 dengan presentase $15 \%$ dengan kriteria sudah tercapai, empat siswa yang mendapatkan skor angket dalam rentang 88-92 dengan presentase 20\% dengan kriteria sudah tercapai, enam siswa yang mendapatkan skor angket dalam rentang 93-97 dengan presentase 30\% dengan kriteria sudah tercapai, lima siswa yang mendapatkan skor angket dalam rentang 98-100 dengan presentase 25\% dengan kriteria sudah tercapai.

Berdasarkan Tabel 3 dan Tabel 4 hasil evaluasi sebelum diberi perlakuan dan hasil evaluasi setelah diberi perlakuan dapat disimpulkan bahwa ada peningkatan skor evaluasi terhadap motivasi belajar siswa sebelum diberi perlakuan dan sesudah diberi perlakuan. Pada rekapan data membuktikan bahwa evaluasi sebelum diberi perlakuan mendapatkan skor evaluasi terendah 14 dan skor evaluasi tertinggi 82 dengan jumlah rata-rata 65,65. Sedangkan skor evaluasi setelah diberi perlakuan yang mendapatkan skor evaluasi terendah 73 dan skor evaluasi tertinggi 100 dengan jumlah rata-rata 92,1.

Selanjutnya akan menghitung uji hipotesis, uji normalitas yang digunakan dalam penelitian ini adalah uji Liliefors dengan taraf signifikan sebesar 0,05, dengan ketentuan bahwa jika $\mathrm{L}_{0}<\mathrm{L}_{\text {tabel }}$ maka data berdistribusi normal. Hasil data uji normalitas tersebut dapat disusun dalam tabel 5.

Tabel 5. Hasil Uji Normalitas Data Awal Dan Data Akhir

\begin{tabular}{ccc}
\hline Keterangan & Pretest & Postest \\
\hline $\mathrm{L}_{0}$ & 0,0949 & 0,08525 \\
Ltabel & 0,190 & 0,190 \\
Kriteria & Berdistribusi Normal & Berdistribusi Normal \\
\hline
\end{tabular}

Berdasarkan Tabel 5 dari hasil uji normalitas data awal (pretest) dan akhir (posttest) kelas dengan taraf signifikan 0,05 dengan jumlah sampel jumlah sampel 20 sehingga didapatkan $\mathrm{L}_{\text {tabel }}=0,190$. Sehingga hasil pretest terdapat $\mathrm{L}_{0}<\mathrm{L}_{\text {tabel }}$ yaitu 0,0949<0,190 maka artinya data berdistribusi normal. Sedangkan hasil posttest terdapat $\mathrm{L}_{0}<\mathrm{L}_{\text {tabel }}$ yaitu 0,08525 $<0,190$ maka artinya data berdistribusi normal. Jadi data nilai posttets menunjukkan bahwa sampel berasal dari populasi berdistribusi normal. Data hasil uji normalitas tersebut selanjutnya dilkukan pengujian hipotesis menggunakan uji $\mathrm{t}$ untuk mengetahui efektif tidaknya media pembelajaran Buku Aktivitas Peta Si Pintar terhadap motivasi belajar siswa dengan rumus sebagai berikut:

$$
t=\frac{\mathrm{Md}}{\sqrt{\frac{\sum x^{2} d}{N(N-1)}}}
$$

Sehingga kriteria perhitungan hipotesis pada uji $t$ ditolak jika $t_{\text {hitung }}>t_{\text {tabel }}$ dan jika $t_{\text {hitung }}<t_{\text {tabel }}$ maka hipotesis diterima. Untuk mengetahui jika memperoleh $t_{\text {tabel }}$ diperlukan menghitung tentang derajat kebebasan $(\mathrm{db})$. Cara untuk memperoleh $\mathrm{db}$ dengan rumus, sebagai berikut :

$\mathrm{Db}=\mathrm{n}-1=20-1=19$

Dengan jumlah db 19 taraf sigifikan 5\%, maka diketahu hasil perhitungan nilai $t_{\text {tabel }}=2,093$. Hasil dari uji $t$ diperolah nilai $t_{\text {hitung }}=7,88$. Jadi disimpulkan dengan jika 
$t_{\text {hitung }}>t_{\text {tabel }}$ yaitu 7,88 $>2,093$, artinya hipotesis ditolak dan dapat disimpulkan media pembelajaran Buku Aktivitas Peta Si Pintar efektif terhadap motivasi belajar siswa tema 2 kegemaranku subtema 2 gemar bernyanyi dan menari kelas I SD Negeri Bugangan 01 Semarang.

Analisis motivasi belajar diperoleh dengan skor sebesar 15,16\% maka mengalami peningkatan motivasi belajar sebelum diberi perlakuan dan sesudah diberi perlakuan. Dengan mengetahui kriteria motivasi belajar diketahui termasuk kategori baik. Dengan demikian dapat disimpulkan bahwa terjadi peningkatan motivasi belajar siswa dengan menerapkan media pembelajaran Buku Aktivitas Peta Si Pintar (Petualangan di Taman Musik Pintar) terhadap motivasi belajar siswa kelas I SD Negeri Bugangan Semarang. Maka indikator keefektifan sesuai yaitu skor ratarata angket motivasi belajar setelah diberi perlakuan lebih tinggi dari pada sebelum diberi perlakuan. Artinya media pembelajaran adalah faktor yang berpengaruh terhadap keberhasilan pembelajaran karena dengan media pembelajaran akan terjadinya interaksi yang baik dan komunikasi menyenangkan antara guru dan siswa (Oktavianti \& Wiyanto, 2014).

Data hasil uji normalitas gain, peningkatan ini diambil dari skor pretest dan posttest yang dikerjakan oleh siswa. Disimpulkan dari angket sebelum diberi perlakuan terbukti seluruh siswa yang terdiri dari 20 semuanya mendapatkan kriteria sedang semua tidak ada siswa yang mendapatkan kriteria motivasi belajar tinggi dan rendah. Sedangkan angket diberi perlakuan terdapat 15 siswa yang mendapat kriteria motivasi belajar tinggi dan lima mendapatkan kriteria motivasi sedang, tidak ada siswa yang mendapatkan kriteria motivasi belajar rendah. Ini membuktikan bahwa hasil angket sebelum dan sesudah diberi perlakuan terdapat siswa satu siswa yang mendapatkan peningkatan motivasi belajar dalam keterangan tinggi, 14 siswa yang mendapatkan peningkatan motivasi belajar dalam keterangan sedang, lima siswa yang mendapatkan peningkatan motivasi belajar dalam keterangan rendah. Sedangkan peningkatan dalam proses soal evaluasi pretes dan posttes dengan hasil rata-rata pada Pretest 65,65 dan hasil posttest 92,1, sedangkan hasil uji Gain terdapat 0,77 kategori tinggi. Sehingga terdapat peningkatan setelah mendapatkan pembelajaran dengan menggunakan media pembelajaran Buku Aktivitas Peta Si Pintar (Petualangan di Taman Musik Pintar

Perhitungan hasil dari uji regresi linier sederhana digunakan untuk mengetahui adanya pengaruh motivasi belajar siswa pada penggunaan media pembelajaran Buku Aktivitas Peta Si Pintar (Petualangan di Taman Musik Pintar) terhadap hasil belajar siswa pada Tema 2 Kegemaranku Subtema 2 Gemar Bernyanyi dan Menari siswa kelas 1 SD N Bugangan 01 Semarang dengan rumus sebagai berikut:

$$
r^{2}=\frac{b\left(N \sum X Y-\sum X \sum Y\right)}{N \sum_{Y} 2-\left(\sum Y\right)^{2}}
$$

Hasil uji regresi linier sederhana diperoleh sebesar $r^{2}=0,0022=0,22 \%$. Sehingga dapat disimpulkan bahwa salah satu faktor yang mempengaruhi prestasi siswa adalah motivasi belajar. Bahwa salah satu faktor yang mempengaruhi prestasi siswa adalah motivasi. Salah satu faktor yang menyebabkan prestasi belajar siswa rendah adalah motivasi belajar siswa (Indriani, 2016). Minat belajar berpengaruh besar terhadap hasil belajar ketika seseorang melakukan sesuatu yang diminati, sebaliknya seseorang tanpa minat tidak akan mungkin melakukan yang diminati (Aritonang, 2008). Kemampuan seseorang untuk memperoleh suatu perubahan tingkah laku melalui interaksi lingkungan dalam 3 aspek yaitu aspek kognitif, aspek afektif, dan 
aspek psikomotor (Slameto, 2003). Oleh karena itu, mutu prestasi belajar siswa harus diperkuat dengan cara meningkatkan motivasi belajar siswa agar menjadi lebih baik.

\section{KESIMPULAN}

Berdasarkan hasil penelitian ini dapat disimpulkan bahwa Media Pembelajaran Buku Aktivitas Peta Si Pintar (Petualangan di Taman Musik Pintar) dapat meningkatkan motivasi belajar siswa.

\section{SARAN}

Media Pembelajaran Buku Aktivitas Peta Si Pintar (Petualangan di Taman Musik Pintar) layak digunakan didalam pembelajaran sehingga memberi pengalaman bermakna kepada siswa. Media Pembelajaran Buku Aktivitas Peta Si Pintar dapat meningkatkan motivasi belajar siswa, namun masih perlu masukan dan perbaikan dalam mengimplementasikan. Hendaknya media pembelajaran seperti Buku Aktvitas Petas Si pintar (Petualangan di Taman Musik Pintar) diterapkan dalam pembelajaran guna memudahkan pemahaman dan antusias belajar dalam pembelajaran.

\section{UCAPAN TERIMAKASIH}

Penelitian ini tidak menerima hibah khusus dari agensi pendanaan mana pun di sektor publik, komersial, atau nirlaba.

\section{DAFTAR PUSTAKA}

Ain, N., \& Kurniawati, M. (2013). Implementasi kurikulum KTSP: Pembelajaran tematik di sekolah dasar. Jurnal Inspirasi Pendidikan, 3(2), 316-328. https://doi.org/10.21067/jip.v3i2.373

Aritonang, K. T. (2008). Minat dan Motivasi dalam Meningkatkan Hasil Belajar Siswa. Jurnal Pendidikan Penabur, 7(10), 11-21.

Baharun, H. (2016, Juli-Desember). Pengembangan Media Pembelajaran PAI Berbasis Lingkungan Melalui Model Assure. Cendekia, 14, 234.

Dimyati, \& Mudjiono. (2015). Belajar Dan Pembelajaran. Jakarta: Rineka Cipta.

Slameto. (2003). Belajar Dan Faktor-Faktor Yang Mempengaruhinya. Jakarta: PT RinekaCipta.

Sugiyono, P. D. (2010). Metode Penelitian Pendidikan. Bandung.

Uno, H. (2016). Teori Motivasi dan pengukuran. Jakarta: Bumi Aksara.

Dewanti, H., Toenlioe, A. J. E., \& Soepriyanto, Y. (2013). Pengembangan Media Pelajaran. Jurnal Pendidikan Teknik Elektro, 3(2), 153.

Handhika, J. (2012). Efektivitas Media Pembelajaran Im3 Ditinjau Dari Motivasi Belajar. $1(2), 109-114$.

Indriani, A. (2016). Pengaruh Motivasi Belajar Siswa Kelas V Terhadap Prestasi Belajar Matematika Di Sd Negeri Bejirejo Kecamatan Kunduran Kabupaten Blora. JIPM $\begin{array}{llll}\text { (Jurnal Ilmiah Pendidikan Matematika), } 134 . & \text { 4(2), }\end{array}$ https://doi.org/10.25273/jipm.v4i2.848

Maghfiroh, L. (2006). Penggunaan Media Flashcard Untuk Meningkatkan Hasil Belajar Ips Pada Pembelajaran Tematik Di Sekolah Dasar. Penggunaan Media Flashcard Untuk Meningkatkan Hasil Belajar IPS, 1-13.

Nataliya, P. (2011). Efektivitas Penggunaan Media Pembelajaran Permainan Tradisional Congklak Untuk Meningkatkan Kemampuan Berhitung Pada Siswa Sekolah Dasar. 
03(02), 343-358.

Nurryna, A. F. (2009). Pengembangan Media Pendidikan Untuk Inovasi Pembelajaran. 1(2), $1-6$.

Octaviani, S. (2017). Pengembangan Bahan Ajar Tematik Dalam Implementasi Kurikulum 2013 Kelas 1 Sekolah Dasar. EduHumaniora | Jurnal Pendidikan Dasar Kampus Cibiru, 9(2), 93. https://doi.org/10.17509/eh.v9i2.7039

Oktavianti, R., \& Wiyanto, A. (2014). Pengembangan Media Gayanghetum (Gambar Wayang Hewan Dan Tumbuhan) Dalam Pembelajaran Tematik Terintegrasi Kelas Iv Sd. Mimbar Sekolah Dasar, 1(1), 65-70. https://doi.org/10.17509/mimbar-sd.v1i1.865

Qondias, D., Anu, E. L., \& Niftalia, I. (2016). Pengembangan Media Pembelajaran Tematik Berbasis Mind Maping Sd Kelas Iii Kabupaten Ngada Flores. JPI (Jurnal Pendidikan Indonesia), 5(2), 176. https://doi.org/10.23887/jpiundiksha.v5i2.8590

Slameto. (2003). Belajar Dan Faktor-Faktor Yang Mempengaruhinya. Jakarta: PT RinekaCipta.

Sugiyono, P. D. (2010). Metode Penelitian Pendidikan. Bandung.

Ulfah, K., Santoso, A., \& Utaya, S. (2016). Hubungan Motivasi Dengan Hasil Belajar Ips. Jurnal Pendidikan - Teori, Penelitian, Dan Pengembangan, 1(8), 1607-1611. https://doi.org/10.17977/jp.v1i8.6678

Uno, H. (2016). Teori Motivasi dan pengukuran. Jakarta: Bumi Aksara

Untari, M. F. A., Arief, B. M., \& Dewi, K. (2019). Pengembangan Media Quiet Book untuk Pembelajaran Tematik Keluargaku. 3(November), 100.

Wahyuni, H. T., Setyosari, P., \& Kuswandi, D. (2016). Implementasi Pembelajaran Tematik Kelas 1 Sd. Edcomtech, 1(2), 129-136.

Worowirastri E., D., Wahyu P.U, I., \& Ika K., D. (2018). Analisis Penggunaan Media Pembelajarantematik Di Sd Muhammadiyah 9 Kota Malang. JINoP (Jurnal Inovasi Pembelajaran), 4(1), 17. https://doi.org/10.22219/jinop.v4i1.4906. 